\title{
Bahan Ajar Menulis Cerita Fantasi Bermuatan Nilai-nilai Kehidupan
}

\author{
Anggun Margaretha S. $\mathrm{P}^{1}$, Imam Agus Basuki ${ }^{1}$, Titik Harsiati ${ }^{1}$ \\ ${ }^{1}$ Pendidikan Bahasa Indonesia-Universitas Negeri Malang
}

\section{INFO ARTIKEL}

\section{Riwayat Artikel:}

Diterima: 18-07-2019

Disetujui: 12-11-2019

\section{Kata kunci:}

writing;

fantasy stories;

teaching materials;

life values;

menulis;

cerita fantasi,

bahan ajar;

nilai-nilai kehidupan

\section{Alamat Korespondensi:}

Anggun Margaretha S. P.

Pendidikan Bahasa Indonesia

Universitas Negeri Malang

Jalan Semarang 5 Malang

E-mail: anggunmargaretha123@gmail.com

Dalam proses pembelajaran bahan ajar memiliki peran penting bagi guru dan siswa. Bahan ajar sebagai segala bentuk bahan yang digunakan untuk membantu guru/instruktur dalam melaksanakan kegiatan belajar mengajar (Depdiknas., 2008). Hal ini berarti bahan ajar tersebut memiliki peranan sebagai alat bantu guru dalam proses pembelajaran. Bahan ajar memiliki peran yang penting untuk pendidik dan peserta didik, dengan bahan ajar yang disusun secara logis dan sistematis kegiatan pembelajaran dapat berjalan berjalan efektif dan efisien (Kapitan, Harsiati, \& Basuki, 2018), (Perwitasari, 2018), (Yogha Pratama, Pratiwi, \& Andajani, 2016), (Khoirotunnisa, Hasanah, \& Dermawan, 2018). Pemilihan bahan ajar pun harus memperhatikan dari isi, penyajian, dan penggunaan bahasa karena berpengaruh terhadap penyampaian kepada siswa. Salah satu manfaat bahan ajar adalah kegiatan penyampaian informasi dalam pembelajaran berjalan efektif antara guru dan peserta didik karena peserta didik akan merasa lebih percaya kepada gurunya (Daryanto dan Dwicahyono, 2014).

Proses pembelajaran tidak lepas dari peranan seorang pendidik sebagai fasilitator. Sebagai fasilitator tersebut, seorang pendidik harus mampu menyediakan bahan ajar yang baik. Akan tetapi, kenyataan di lapangan masih banyak pendidik yang belum bisa menyediakan bahan ajar yang baik dan sesuai dengan kebutuhan siswanya. Kebanyakan pendidik hanya bergantung pada buku yang disediakan pemerintah.

Mata pelajaran bahasa Indonesia merupakan pembelajaran berbasis teks dalam Kurikulum 2013. Pembelajaran berbasis teks tersebut yang digunakan sebagai dasar pengembangan kompetensi dasar mata pelajaran bahasa Indonesia pada Kurikulum 2013 (Priyatni, 2015). Salah satu jenis teks yang diajarkan pada siswa SMP kelas VII semester ganjil adalah cerita fantasi. Cerita fantasi tersebut dapat dimasukkan pada keterampilan menulis. Untuk mengembangkan keterampilan menulis teks cerita fantasi, siswa memerlukan petunjuk memadai yang mengarahkan pada kegiatan menulis teks cerita fantasi secara bertahap. Oleh karena itu, perlu merancang kegiatan secara maksimal supaya hasil dari keterampilan menulis juga maksimal.

Keterampilan menulis bukanlah suatu kegiatan yang mudah. Menulis bukan hanya sekedar menuangkan pemikiran kreatifnya dan apa yang dipikirkan. Akan tetapi, menulis juga harus memperhatikan pemahaman pembaca atas apa yang kita tulis. Hal ini yang masih sulit untuk dilakukan karena kebanyakan hanya memikirkan pemikiran kreatif apa yang ditulis dan mengabaikan pemahaman pembaca. Oleh karena itu, kegiatan menulis memerlukan pedoman yang baik dari segi isi, penyajian, dan penggunaan bahasa. 
Fokus penelitian ini pada keterampilan menulis, yaitu menulis cerita fantasi bermuatan nilai-nilai kehidupan yang dilakukan oleh siswa. Keberhasilan kompetensi menulis cerita fantasi yang bermuatan nila-nilai kehidupan perlu adanya bahan ajar yang baik dan sesuai untuk memfasilitasi siswa dalam kegiatan pembalajaran. Produk bahan ajar yang dikembangkan dalam penelitian berupa buku teks siswa dengan rangsang yang bervariasi. Bahan ajar tersebut dibutuhkan siswa dalam menulis cerita fantasi yang bermuatan nilai-nilai kehidupan.

Pembelajaran menulis cerita fantasi dianggap penting untuk diperhatikan karena mendukung program penumbuhan karakter di sekolah. Cerita fantasi dapat memotivasi peserta didik. Dengan cerita fantasi siswa akan berimajinasi dan berfantasi menjadi tokoh yang ada dalam cerita. Dengan begitu siswa dapat membayangkan menjadi seseorang yang mendapat masalah hidup dan dapat menyelesaikan permasalahannya. Selain itu, siswa dapat mengenal berbagai macam sifat manusia. Hal ini dapat dilihat dari pelaku tokoh dalam cerita, baik perilaku baik maupun buruk. Dengan adanya muatan nila-nilai kehidupan dalam cerita fantasi diharapkan siswa dapat meneladani sifat baik dalam diri mereka. Hal ini sejalan dengan pendapat (Jannah, Suwignyo, \& Harsiati, 2019) bahwa cerita fabel yang mengandung nilai moral dapat menambah pengetahuan peserta didik.

Muatan nilai-nilai kehidupan dipilih karena sesuai dengan program pendidikan karakter di sekolah. Muatan nilai-nilai kehidupan terdiri dari sikap kepedulian, kedisiplinan, dan tanggung jawab. Muatan tersebut diharapkan dapat membuat peserta didik menjadi pribadi yang lebih baik lagi. Menurut (Wening, 2012) bahwa pembelajaran cerita dengan muatan nilai kehidupan dapat membentuk karakter peserta didik. Akan tetapi, hal ini tidak sejalan dengan pendapat (Anugraheny, Hasanah, \& Siswanto, 2019) bahwa perubahan karakter peserta didik dapat terwujud jika mereka dapat mengubah pandangannya sendiri tentang nilainilai kehidupan.

Pemilihan fokus tersebut juga didasarkan pada hasil analisis kebutuhan di sekolah. Berdasarkan analisis kebutuhan diketahui bahwa buku dari pemerintah menjadi pedoman utama dalam pembelajaran Bahasa Indonesia sehingga peserta didik kurang mendapat pengetahuan dan wawasan yang luas. Oleh karena itu, diperlukan bahan ajar sebagai pendamping buku dari pemerintah agar dapat mencapai kompetensi yang diharapkan. Tujuan penelitian pengembangan ini adalah menghasilkan produk berupa bahan ajar menulis cerita fantasi bermuatan nilai-nilai kehidupan untuk siswa kelas VII. Selain itu, menguji keefektifan produk bahan ajar untuk melihat kelayakan produk yang diimplementasikan.

\section{METODE}

Model yang digunakan pada penelitian pengembangan ini adalah Model 4-D ini terdiri atas empat tahap, yaitu (1) define, (2) design, (3) development, dan (4) disseminate. Model 4-D dipilih bertujuan untuk menghasilkan produk bahan ajar yang sistematis. Tahapan model tersebut dijelaskan sebagai berikut.

Pertama, define (penetapan). Penetapan disini berarti memerlukan analisis kebutuhan yang dilakukan di lapangan untuk mengetahui kebutuhan bahan ajar yang dikembangkan. Studi pendahuluan dilakukan agar peneliti mengetahui kebutuhan produk yang akan dikembangkan (Romadhon \& Basuki, 2018) dan (Firdian \& Maulana, 2018). Kegiatan tersebut dilakukan dengan menganalisis Kurikulum 2013, menganalisis kebutuhan di sekolah, menganalisis bahan ajar yang digunakan di sekolah, dan menelaah program penumbuhan karakter di sekolah. Hal ini bertujuan untuk menentukan produk yang akan dikembangkan.

Kedua, design (perencanaan). Perencanaan berarti peneliti membuat perencanaan produk yang akan dikembangkan. Perencanaan produk dilakukan dengan merumuskan indikator berdasarkan kompetensi yang ingin dicapai. Setelah itu, memilih materi dan cerita fantasi yang sesuai dengan pembelajaran cerita fantasi. Lalu, merencanakan draf awal bahan ajar yang akan dikembnagkan.

Ketiga, development (pengembangan). Tahap pengembangan ini bertujuan untuk menyempurnakan produk melalui uji ahli pembelajaran menulis, ahli bahan ajar, uji praktisi dan siswa. Produk yang telah direncanakan diujikan oleh uji ahli pembelajaran menulis, ahli bahan ajar dan uji praktisi. Hasil uji tersebut berupa saran dan komentar yang digunakan untuk menyempurnakan produk bahan ajar sebelum digunakan di lapangan. Setelah di revisi, produk bahan ajar di uji coba pada siswa kelas VII.

Keempat, disseminate (penyebaran). Tahap penyebaran terdiri dari dua kegiatan, yaitu memberikan produk bahan ajar di sekolah sebagai buku pendamping dan melakukan penulisan artikel. Pemberian bahan ajar di sekolah bertujuan agar bahan ajar yang dikembangkan dapat digunakan sebagai pendamping buku pemerintah yang disediakan di sekolah. Penulisan artikel dilakukan untuk laporan bahwa bahan ajar yang dikembangkan sudah layak dan efektif untuk digunakan di pembelajaran.

Data yang dihasilkan dalam penelitian ini berupa data verbal dan data numerik. Data verbal berupa saran dan komentar dari hasil uji kelayakan oleh ahli pembelajaran menulis, ahli bahan ajar, praktisi, dan siswa, sedangkan data numerik berupa nilai yang didapat dari hasil uji kelayakan produk dan uji keefektivitas produk.

Analisis data yang dilakukan pada penelitian ini, yaitu analisis data verbal dan data numerik. Analisis data verbal berupa saran dan komentar saat uji kelayakan produk. Sedangkan analisis data numerik berupa nilai dalam bentuk presentase yang diperoleh dari angket uji kelayakan produk dan uji keefektivitas produk.

Uji keefektifan produk dilakukan bertujuan untuk mengetahui pengaruh produk bahan ajar menulis cerita fantasi bermuatan nilai-nilai kehidupan efektif digunakan di lapangan dengan uji praeksperimen pada satu kelompok kelas VII-J SMP Negeri 1 Pagu. Uji praeksperimen menghasilkan uji pretes dan uji postes. Dalam hasil tersebut dapat dilihat perbandingan nilai peserta didik saat sebelum dan sesudah menggunakan produk yang dikembangkan. 


\section{HASIL}

Hasil penelitian pengembangan ini berupa produk bahan ajar untuk pembelajaran menulis cerita fantasi. Akan tetapi, bahan ajar dalam penelitian ini terdapat modifikasi dengan menambahkan muatan nilai-nilai kehidupan pada tiap cerita fantasi dalam buku tersebut. Judul bahan ajar tersebut adalah Menulis Cerita Fantasi Bermuatan Nilai-nilai Kehidupan. buku tersebut terdiri dari tiga unit, yaitu (a) ayo menulis cerita fantasi dengan mengedepankan kepedulian, (b) ayo menulis cerita fantasi dengan mengedepankan kedisiplinan, dan (c) ayo menulis cerita fantasi dengan mengedepankan tanggung jawab. Bahan ajar tersebut dikembangkan dengan memperhatikan empat aspek, yaitu kelayakan isi, kelayakan penyajian buku, kelayakan bahasa buku, dan kelayakan kegrafisan (tampilan) buku.

Data kelayakan isi buku dibagi menjadi tiga aspek, yaitu kelengkapan isi materi, kedalaman isi materi, dan keakuratan materi bahan ajar. Data kelayakan tersebut diperoleh dari penilaian ahli pembelajaran menulis, praktisi, dan siswa. Hasil uji kelayakan isi buku mendapat skor $83 \%$ dari ahli pembelajaran menulis, $88 \%$ dari praktisi, dan $78 \%$ dari siswa. Rata-rata skor uji kelayakan isi buku diperoleh sebesar $83 \%$. Skor tersebut masuk dalam kualifikasi layak karena berada pada rentangan $75-84 \%$. Hal tersebut berarti isi produk dapat diimpelemntasikan dalam buku siswa.

Data kelayakan penyajian buku dibagi menjadi empat aspek, yaitu sistematika penyajian buku, penyajian pembelajaran, kelengkapan penyajian, dan penyajian pembelajaran menulis cerita fantasi. Data kelayakan tersebut diperoleh dari penilaian ahli pembelajaran menulis, ahli bahan ajar, praktisi, dan siswa. Hasil uji kelayakan penyajian buku mendapat skor $80 \%$ dari ahli pembelajaran menulis, $95 \%$ dari ahli bahan ajar, $82 \%$ dari praktisi, dan $76 \%$ dari siswa. Rata-rata skor uji kelayakan penyajian buku diperoleh sebesar 83\%. Skor tersebut masuk dalam kualifikasi layak karena berada pada rentangan 75-84\%. Hal tersebut berarti penyajian produk dapat diimplementasikan dalam bahan ajar.

Data kelayakan bahasa buku dibagi menjadi dua aspek, yaitu keakuratan dan kekomunikatifan. Data kelayakan tersebut diperoleh dari penilaian ahli pembelajaran menulis, ahli bahan ajar, praktisi, dan siswa. Hasil uji kelayakan bahasa buku mendapat skor $96 \%$ dari ahli pembelajaran menulis, $88 \%$ dari ahli bahan ajar, $80 \%$ dari praktisi, dan $81 \%$ dari siswa. Rata-rata skor uji kelayakan bahasa buku diperoleh sebesar $86 \%$. Skor tersebut masuk dalam kualifikasi sangat layak karena berada pada rentangan 85\%-100\%. Hal tersebut berarti aspek penggunaan bahasa produk dapat diimplementasikan dalam bahan ajar.

Data kelayakan kegrafisan yang dimaksudkan adalah data kelayakan desain tampilan buku. Data kelayakan tersebut dibagi menjadi lima aspek, yaitu (1) ukuran dan jenis huruf, (2) tata letak, (3) ilustrasi, (4) desain sampul, dan (5) desain isi. Data kelayakan tersebut diperoleh dari penilaian ahli pembelajaran menulis, ahli bahan ajar, praktisi, dan siswa. Hasil uji kelayakan kegrafisan (tampilan) buku mendapat skor $80 \%$ dari ahli pembelajaran menulis, $80 \%$ dari ahli bahan ajar, $88 \%$ dari praktisi, dan 93\% dari siswa. Rata-rata skor uji kelayakan kegrafisan buku diperoleh sebesar $85 \%$. Skor tersebut masuk dalam kualifikasi sangat layak karena berada pada rentangan 85-100\%. Hal tersebut berarti kegrafisan atau desain tampilan produk dapat diimplementasikan dalam bahan ajar.

Uji keefektifan produk dilakukan dengan uji praeksperimen one group pretest-posttest pada tahap pelaksanaan dari hasil pretes dan hasil postes setelah mengimplementasikan bahan ajar pada pembelajaran. Hasil uji keefektifan produk diuji dengan peneliti melakukan uji normalitas untuk mengetahui data terdistribusi normal menggunakan analisis one sample kolmogorov smirnov test pada satu kelompok kelas VII-J tanpa ada kelas kontrol.

Tabel 1. Hasil Uji Normalitas Data

\begin{tabular}{|c|c|c|c|}
\hline \multicolumn{4}{|c|}{ One-Sample Kolmogorov-Smirnov Test } \\
\hline & & Pretes & postes \\
\hline $\mathrm{N}$ & & 32 & 32 \\
\hline \multirow[t]{2}{*}{ Normal Parameters ${ }^{a}$} & Mean & 68.3750 & 78.5312 \\
\hline & Std. Deviation & 8.65373 & 6.38033 \\
\hline \multirow[t]{3}{*}{ Most Extreme Differences } & Absolute & .113 & .157 \\
\hline & Positive & .113 & .157 \\
\hline & Negative & -.106 & -.102 \\
\hline Kolmogorov-Smirnov Z & & .639 & .890 \\
\hline Asymp. Sig. (2-tailed) & & .808 & .407 \\
\hline
\end{tabular}

a. Test distribution is Normal 
Dari tabel 1, dapat diketahui hasil uji normalitas data pretes sebesar 0,808 dan hasil uji normalitas data postes sebesar 0,407. Persebaran data dapat dikatakn normal apabila hasil uji normalitas lebih besar dari 0,05. Hasil penghitungan data pretes dan postes pada uji normalitas ini lebih besar dari 0,05 sehingga dapat dikatakan data berdistribusi normal.

Tabel 2. Uji Paired Test (Uji-T)

\begin{tabular}{|cc|c|c|c|c|}
\hline & Mean & $\mathrm{N}$ & Std. Deviation & Std. Error Mean \\
\hline \multirow{2}{*}{ Pair 1 } & pretes & 68.3750 & 32 & 8.65373 & 1.52978 \\
& & & & \\
& postes & 78.5312 & 32 & 6.38033 & 1.12789 \\
\hline
\end{tabular}

\begin{tabular}{|c|c|c|c|c|}
\hline \multicolumn{5}{|c|}{ Paired Samples Correlations } \\
\hline & & $\mathrm{N}$ & Correlation & Sig. \\
\hline Pair 1 & pretes \& postes & 32 & .696 & .000 \\
\hline
\end{tabular}

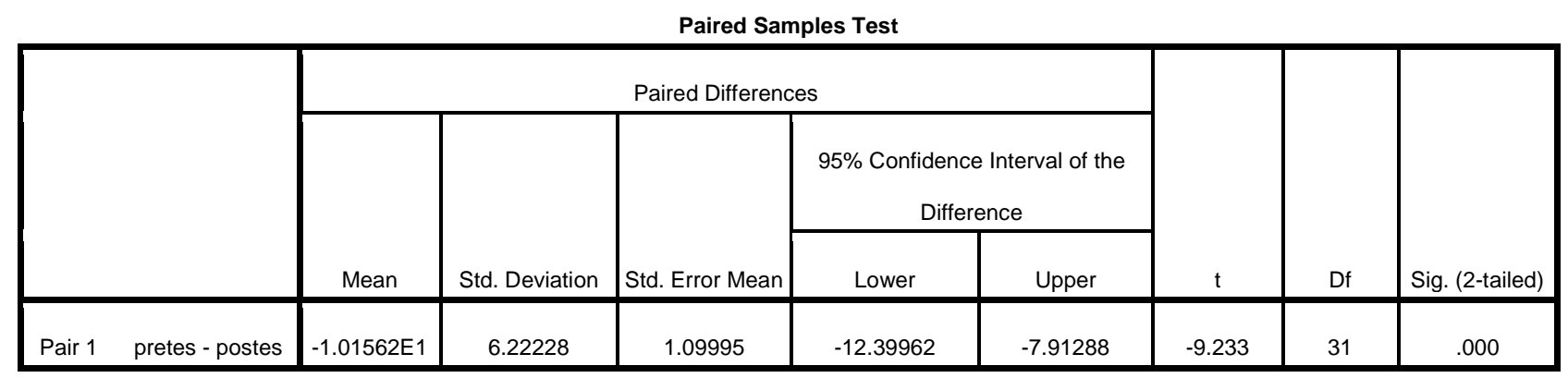

Pada tabel 2 diketahui nilai $\mathrm{t}=-9,233$, sedangkan probabilitas uji beda menunjukkan angka 0,000. Hal tersebut berarti probabilitas yang dihasilkan berada di bawah ketetapan probabilitas penelitian ilmu sosial sebesar 0,05. Jadi, dapat dikatakan bahwa terdapat perbedaan yang signifikan nilai menulis cerita fantasi siswa sebelum dan setelah menggunakan bahan yang dikembangkan. Hal ini sejalan dengan pendapat (Dewi \& Suwignyo, 2018) bahwa untuk mengetahui efektivitas dapat dilakukan dengan uji paired sample test. Oleh karena itu, bahan ajar yang dikembangkan dalam penelitian ini efektif untuk diimplementasikan.

\section{PEMBAHASAN}

Penelitian ini menghasilkan produk berupa bahan ajar menulis cerita fantasi bermuatan nilai-nilai kehidupan. Bahan ajar tersebut Menulis Cerita Fantasi Bermuatan Nilai-nilai Kehidupan. Bahan ajar ini dapat digunakan sebagai buku pendamping tidak menggantikan buku Kemendikbud yang telah disediakan di sekolah. Hal ini sesuai dengan pendapat (Depdiknas., 2008) yang menyatakan bahwa bahan ajar terdiri dari dua jenis, yaitu bahan ajar utama dan bahan ajar pendamping. Bahan ajar suplemen diharapkan dapat menambah pengetahuan siswa. Bahan ajar yang dikembangkan disajikan dalam empat aspek, yaitu isi buku, penyajian buku, bahasa buku, dan kegrafisan buku.

Pertama, isi bahan ajar disesuaikan dengan Kompetensi Dasar dalam Kurikulum 2013 revisi 2017. Isi bahan ajar tersebut ditekankan pada KD 4.4 yaitu menyajikan gagasan kreatif dalam bentuk cerita imajinasi (fantasi) secara lisan dan tulis dengan memperhatikan struktur dan penggunaan bahasa. Produk bahan ajar ini telah direvisi dengan menambah sumber pada setiap cerita, menambahkan contoh pengerjaan latihan, dan memaparkan peta konsep pada buku. Pertama, sebagian cerita pada bahan ajar belum mencantumkan sumber cerita sehingga kurang meyakinkan keakuratannya. Keakuratan informasi dalam bahan ajar berguna untuk memperkaya wawasan siswa (Majid, 2009). Oleh karena itu, perlu menambahkan sumber tiap cerita agar lebih jelas keakuratannya. Kedua, menambahkan contoh pengerjaan latihan karena agar siswa tidak kesulitan dalam mengerjakan latihan pada buku. Hal ini sejalan dengan pendapat (Depdiknas, 2008) bahwa dengan adanya bahan ajar siswa mendapatkan kemudahan dalam mempelajari setiap kompetensi yang harus dicapai. Ketiga, memaparkan peta konsep karena supaya mempermudah siswa dalam memahami materi pada buku. 
Kedua, penyajian bahan ajar meliputi sistematika penyajian buku, penyajian pembelajaran, kelengkapan penyajian, dan penyajian pembelajaran menulis cerita fantasi. Sistematika penyajian telah direvisi dengan memperjelas petunjuk penggunaan buku dapat mempermudah siswa dan guru dalam memahami isi bahan ajar tersebut. Panduan atau perintah yang jelas dapat mempermudah siswa untuk memahami materi, contoh, dan mengerjakan latihan (Muslich, 2010). Kelengkapan penyajian telah direvisi ada dua hal, yaitu menambahkan contoh konkret nilai-nilai kehidupan pada kotak info agar siswa lebih mudah dalam mengembangkan karakter diri dan menambahkan peta konsep pada awal unit untuk mempermudah siswa dalam memahami materi yang akan dipelajari.

Ketiga, kebahasaan bahan ajar terdiri dua aspek, yaitu keakuratan dan kekomunikatifan. (Sitepu, 2015) berpendapat bahwa bahasa menggunakan kaidah tertentu sehingga pesan yang berupa gagasan dan/atau perasaan pengirim dapat tersampaikan secara tepat. Penggunaan bahasa bahan ajar telah direvisi dengan menyunting kesalahan ejaan, tanda baca, salah ketik, dan kalimat ambigu. Penyuntingan tidak hanya dilakukan pada bagian isi tetapi juga bagian bahasa. Hal tersebut sejalan dengan pendapat (Pujiono, 2013) yang menyatakan bahwa aspek menyunting terdiri dari menyunting isi, struktur, dan kebahasan yang meliputi ejaan dan tanda baca.

Keempat, kegrafisan (tampilan) dibagi menjadi lima aspek, yaitu (1) ukuran dan jenis huruf, (2) tata letak, (3) ilustrasi, (4) desain sampul, dan (5) desain isi. Pertama, bahan ajar telah direvisi dengan memperbaiki pewarnaan pada buku. Kedua, bahan ajar telah direvisi dengan memperbaiki ilustrasi ikon tiap kegiatan disamakan. Ketiga, desain sampul, bahan ajar telah direvisi dengan mengubah ilustrasi pada sampul agar menggambarkan isi bahan ajar. Hal tersebut sesuai dengan pendapat Krustianto (2009) yang menyatakan bahwa penyajian gambar difungsikan untuk menyampaikan pesan pada tulisan.

\section{SIMPULAN}

Penelitian ini menghasilkan produk berupa bahan ajar menulis cerita fantasi bermuatan nilai-nilai kehidupan. Bahan ajar tersebut Menulis Cerita Fantasi Bermuatan Nilai-nilai Kehidupan. Selain itu, penelitian ini juga melakukan uji efektivitas bahan ajar yang telah dikembangkan. Hal ini bertujuan untuk mengetahui efektivitas produk dilakukan dengan kegiatan pretes dan postes.

Produk berupa buku siswa yang dikembangkan telah melewati uji kelayakan dan uji keefektifan. Pertama, uji kelayakan produk dari ahli pembelajaran menulis, ahli bahan ajar, praktisi, dan siswa telah diperoleh hasil kelayakan isi buku siswa sebesar $83 \%$, kelayakan penyajian buku siswa sebesar $83 \%$, kelayakan bahasa buku siswa sebesar $86 \%$, dan kelayakan tampilan buku siswa sebesar $85 \%$. Rata-rata hasil uji kelayakan produk adalah $85 \%$ yang berarti bahan ajar yang dikembangkan sangat layak untuk diimplementasikan. Kedua, berdasarkan uji keefektifan produk, diketahui nilai t= $-9,233$ dan probabilitas menunjukkan $0,000(\mathrm{p}<0,05)$. Jadi, dapat dikatakan bahwa terdapat perbedaan yang signifikan nilai menulis cerita fantasi siswa sebelum dan setelah menggunakan bahan yang dikembangkan. Dengan kata lain, bahan ajar Menulis Cerita Fantasi Bermuatan Nilai-nilai Kehidupan efektif untuk diimplementasikan. Berdasarkan uji kelayakan dan keefektifan, bahan ajar Menulis Cerita Fantasi Bermuatan Nilai-nilai Kehidupan dapat dijadikan pendamping atau suplemen buku utama dari pemerintah.

Saran pemanfaatan untuk siswa. Bahan ajar yang dikembangkan dapat dimanfaatkan sebagai pendamping buku utama yang telah digunakan di sekolah. Selain itu, bahan ajar ini dapat membantu siswa untuk menulis cerita fantasi dengan mudah serta dapat digunakan sebagai wahana pembelajaran nilai kehidupan sesuai dengan program yang ada di sekolah.

Saran pemanfaatan bagi guru bahasa Indonesia bahan ajar yang dikembangkan dapat digunakan sebagai referensi ketika mengajarkan materi menulis cerita fantasi serta dapat digunakan untuk menuntun siswa mempelajari nilai kehidupan dari tiap kegiatan dalam bahan ajar. Bahan ajar juga dapat digunakan guru sebagai referensi dalam menghasilkan latihan yang variatif.

Bagi peneliti lain, bahan ajar yang dikembangkan dapat digunakan sebagai dasar untuk mengembangkan produk lain yang lebih variatif dan menarik. Selain itu, bahan ajar yang dikembangkan juga dapat dijadikan sebagai rujukan dalam penyusunan bahan ajar teks-teks lain.

Saran diseminasi produk yang dikembangkan dapat disebarluaskan dengan dua cara berikut. Pertama, penyebarluasan laporan pengembangan produk dilakukan melalui penulisan jurnal ilmiah agar dapat dibaca dan dijadikan rujukan peneliti lanjutan. Kedua, penyebarluasan produk yang telah dihasilkan dilakukan dengan memberikan bahan ajar kepada guru bahasa Indonesia dan siswa di SMP Negeri 1 Pagu.

\section{DAFTAR RUJUKAN}

Anugraheny, R., Hasanah, M., \& Siswanto, W. (2019). Bahan Ajar Menulis Cerita Pendek Bermuatan Nilai-Nilai Kenabian untuk Siswa MTs Kelas VII. Jurnal Pendidikan: Teori, Penelitian, dan Pengembangan, 4(2), 206-212.

Daryanto dan Dwicahyono, A. (2014). Pengembangan Perangkat Pembelajaran: Silabus, RPP, PHB, Bahan Ajar. Yogyakarta: Gava Media.

Depdiknas. (2008). Panduan Pengembangan Bahan Ajar. Jakarta: Departemen Pendidikan Nasional.

Dewi, H. G., \& Suwignyo, H. (2018). Bahan Ajar Menulis Teks Fabel Bermuatan Nilai Kehidupan. 1032-1038.

Firdian, F., \& Maulana, I. T. (2018). Pengembangan Media Pembelajaran Multimedia Interaktif pada Matakuliah Aplikasi Software. Jurnal Pendidikan: Teori, Penelitian, dan Pengembangan, 3(6), 822-828.

Jannah, E. M. N., Suwignyo, H., \& Harsiati, T. (2019). Analisis Nilai-nilai Karakter Hasil Karya Menulis Kreatif Siswa. Jurnal Pendidikan: Teori, Penelitian, dan Pengembangan, 4(2), 149-155. 
Kapitan, Y. J., Harsiati, T., \& Basuki, I. A. (2018). Pengembangan Bahan Ajar Menulis Teks Cerita Fantasi Bermuatan Nilai Pendidikan Karakter di Kelas VII. Jurnal Pendidikan: Teori, Penelitian, dan Pengembangan, 3(1), 100-106.

Khoirotunnisa, R. P., Hasanah, M., \& Dermawan, T. (2018). Pengembangan Bahan Ajar Menulis Pantun Bermuatan Nilai Budaya dengan Strategi Pohon Kata untuk Siswa Kelas VII. Jurnal Pendidikan: Teori, Penelitian, dan Pengembangan, $3(8), 238-244$.

Majid, A. (2009). Perencanaan Pembelajaran (Mengembangkan Standar Kompetensi Guru). Bandung: PT Remaja Rosda Karya.

Muslich, M. (2010). Text Book Writing. Yogyakarta: Ar-Ruzz Media.

Perwitasari, S. W. S. A. (2018). Pengembangan Bahan Ajar Tematik Berbasis Kontekstual. Jurnal Pendidikan: Teori, Penelitian, dan Pengembangan, 3(2014), 278-285.

Pratama, F. Y., Pratiwi, Y., \& Andajani, K. (2016). Pengembangan Bahan Ajar Menulis Teks Eksposisi Bermuatan Cinta Lingkungan dengan Strategi Pemodelan untuk Siswa Kelas VII SMP. Jurnal Pendidikan: Teori, Penelitian, dan Pengembangan, 1(3), 448-462.

Priyatni, E. T. (2015). Pembelajaran Bahasa Berbasis Teks. Makalah Disajikan dalam Kegiatan Prapasca, Jurusan Pendidikan Bahasa Indonesia, Malang, 15 Agustus 2015.

Pujiono, S. (2013). Terampil Menulis. Yogyakarta: Graha Ilmu.

Romadhon, S. D., \& Basuki, I. A. (2018). Bahan Ajar Menulis Artikel Opini dengan Metode Pembelajaran Curah Gagasan. Jurnal Pendidikan: Teori, Penelitian, dan Pengembangan, 3(2), 215-222.

Sitepu. (2015). Penulisan Buku Teks Pelajaran. Bandung: PT Remaja Rosdakarya. Bandung: PT Remaja Rosdakarya.

Wening, S. (2012). The Nation's Character Building Through Value Education. Jurnal Pendidikan Karakter, 2(1), 55-66. https://doi.org/10.21831/JPK.V0I1.1452 